\title{
Microbial inciters of acute asthma in urban Nigerian children
}

\author{
Daniel A Gbadero, Abdul-Wahab B R Johnson, Wilson I Aderele, O D Olaleye
}

\begin{abstract}
Background - In tropical Africa the role of microbial agents of acute respiratory infections in acute exacerbations of bronchial asthma remains largely unexplored. However, empirical antibacterial therapy is frequently initiated in moderate to severe cases of acute asthma with symptoms of acute respiratory infection. A study was set up to determine how often acute respiratory infection is associated with acute asthma, to identify the associated pathogens, and to proffer appropriate therapeutic suggestions.

Methods - Over a 16 month period, 86 episodes of acute asthma were studied for clinical and laboratory features of acute respiratory infection at the University College Hospital (UCH), Ibadan. Virological diagnosis was based on immunofluorescence studies of nasopharyngeal aspirates and/or serological tests using the microtitre complement fixation technique. Throat swabs and blood were cultured for bacterial agents.
\end{abstract}

Results - Of the 64 cases who presented with rhinorrhoea, $51(79.7 \%)$ were pyrexial $\left(T \geqslant 37 \cdot 6^{\circ} \mathrm{C}\right)$. Inflammatory changes (frequently interstitial streakiness) were identified in $10(19.6 \%)$ of the 51 chest radiographs; only two of these had lobar shadowing. Significant bacterial isolates were made in only three (3.5\%) of the throat swabs and two $(2 \cdot 4 \%)$ of the blood cultures from the 86 cases; none had clinical septicaemia. On the other hand, 55 viral agents were identified from $39(53 \%)$ of the 74 subjects studied; $16(41.0 \%)$ had dual viral identifications. Respiratory syncytial virus (RSV) accounted for $20(36.4 \%)$ identifications, parainfluenza virus (PIV) type 3 for $15(27 \cdot 3 \%)$, and influenza type A (Flu A) for $12(21 \cdot 8 \%)$. Viral identifications were significantly higher in infants and preschool subjects ( $<5$ years) and in those presenting with either rhinorrhoea or pyrexia. Conclusions - The results of this study underscore the importance of viral upper respiratory infections in asthma exacerbations in a tropical setting. The paucity of clinical and investigative features of bacterial acute respiratory infection suggests that there is little rationale for routine antibiotic cover in children with acute exacerbations of asthma in the tropics.

(Thorax 1995;50:739-745)

Keywords: acute asthma, acute respiratory infections, viral respiratory infections, bacterial acute respiratory infections, tropical Africa.
Along with pulmonary tuberculosis, bronchial asthma remains a common cause of chronic ambulatory respiratory morbidity in the West African subregion. ${ }^{12}$ It is envisaged that, with the inevitable atmospheric pollution from increasing urbanisation and industrialisation, paediatric asthma morbidity in the tropics may approach the current "epidemic" proportions of the western world. ${ }^{3}$ Acute respiratory infections currently constitute a research priority area worldwide, and justifiably so in the third world where mortality related to acute resiratory infections continues to soar. ${ }^{4}$ Although reports from Europe and North America have suggested that viruses are the important infective triggers of acute asthma in childhood, ${ }^{5-8}$ there is a shortage of accessible data on this aspect of the disease in the African subregion. An earlier report by Aderele $^{9}$ highlighted the difficulties in evaluating the relative importance of an antecedent/concomitant respiratory infection as a precipitating factor of acute asthma in Nigerian children. The fact that bacterial pathogens have been identified as the predominant aetiological agents of childhood acute respiratory infection in the developing world ${ }^{4}$ may therefore partly explain the general tendency for practitioners in the tropics to institute routine antibacterial agents for children presenting with moderate to severe episodes of acute asthma and acute respiratory infection symptoms. The microbiological implications of this therapeutic strategy, including the selection of drug-resistant agents, are selfevident. With these in mind the current study was designed to assess the possible importance of acute respiratory infections as trigger factors of acute asthma, to identify the important pathogens and, if need be, to suggest a rational antimicrobial strategy.

\section{Methods}

STUDY POPULATION, RECRUITMENT PROCEDURE AND SELECTION CRITERIA

Subjects were recruited over 16 months from previously diagnosed asthmatic children attending the Paediatric Asthma Clinic of the University College Hospital (UCH), Ibadan. $\mathrm{UCH}$ is Nigeria's premier tertiary health care institution with 800 beds including 150 for children. The principal catchment area is Ibadan City, situated in the tropical rain forest belt of south-western Nigeria. There are two major seasons comprising a six-month rainy stretch with a cool and dusty harmattan transition to the hot dry season. With over two million inhabitants, most of whom are artisans, petty traders, and farmers on low incomes 
living in substandard and overcrowded accommodation, ${ }^{10}$ the Ibadan community constitutes a typical urban tropical setting. The estimated local incidence of paediatric acute respiratory infection was $6 \cdot 1-8 \cdot 1$ episodes per child per year. ${ }^{10}$ Further background data on the study population have been highlighted elsewhere. ${ }^{10}$

The diagnosis of bronchial asthma in all potential subjects was based on a history of at least three episodic attacks of wheezy dyspnoea (frequently nocturnal), along with other features as detailed earlier. ${ }^{1}$ At recruitment the central inclusion criterion was a diagnosis of acute asthma, based on the presence of features of an acute exacerbation as described elsewhere. ${ }^{112}$ In a previously stable asthmatic patient these comprised a variable combination of (1) a history of sudden onset of shortness of breath/chest "tightness" and paroxysms of cough frequently associated with a wheeze; (2) prolonged and difficult expiratory phase of breathing, often associated with soft tissue recession of the lower chest wall and, in severe cases, physical signs of hyperinflation (that is, increased anteroposterior diameter of the thoracic cage with a round shouldered posture and bilateral hyperresonant notes); and (3) bilateral but predominantly expiratory high pitched polyphonic rhonchi. Spirometric measurements of expiratory airways obstruction were not made because it was not part of our routine management of acute exacerbations. Exclusion criteria in otherwise eligible cases comprised a symptom duration of $\geqslant 48$ hours, clinical or radiographic features of "air leak" complications such as pneumothorax, subcutaneous or interstitial emphysema, and refusal of parents to give consent. Only one episode was recorded per subject studied. After the initial brief clinical evaluation bronchodilator therapy was given to those with severe respiratory distress before pursuing ancillary investigations. For others with less severe distress these investigations were undertaken before specific therapy. In all cases a detailed clinical evaluation was eventually obtained with emphasis on antecedent or concomitant symptoms of acute respiratory infection, household/ socioeconomic risk factors of acute respiratory infection, ${ }^{10}$ and frequent asthma exacerbations. ${ }^{912}$ Anthropometric measurements were also made for appropriate nutritional categorisation using the local weight and height reference charts of Janes ${ }^{13}$ and the Wellcome criteria. $^{14}$

A posteroanterior chest radiograph was requested as soon as possible after the initial clinical evaluation. Subsequent reports were made blindly by qualified radiologists who were not part of the study team. Venous blood $(8-10 \mathrm{ml})$ was obtained aseptically for serodiagnosis, bacterial cultures, and haematological screening. A nasopharyngeal aspirate was taken for virological studies as detailed below. Following the initial therapeutic measures each subject was re-evaluated after about 30 minutes to determine the need for additional treatment. Those with significant improvement and in whom this was sustained for up to four hours of subsequent observation were discharged home on oral salbutamol, while those with persistent symptoms were admitted as severe acute asthma for further care. Evaluation after discharge was at the same asthma clinic and, in appropriate cases, the convalescence serological specimen was taken.

\section{VIROLOGICAL STUDIES}

Nasopharyngeal aspirates were obtained for the first few months by improvising an appropriately sized nasogastric tube, inserted with the distal tip at the nasopharynx and the proximal end attached to a $10-20 \mathrm{ml}$ syringe with which a suction pressure was generated. Later in the course of the study a soft catheter with a mucus trap (Nunc, Roskilde, Denmark) and a medium-sized vacuum pump became available for collection of nasopharyngeal aspirates. Specimens were rinsed and mixed thoroughly with 3-4 ml of the viral transport medium (Hank's balanced salt solution (BSS, Gibco, New York, USA)) and delivered to the laboratory (situated on the hospital premises) within 15-20 minutes of collection.

\section{Immunofluorescence technique}

After a $4^{\circ} \mathrm{C}$ refrigerated centrifugation, cell pellets were separated within 24 hours of collection and washed in phosphate buffered saline (PBS). A smear preparation was then made on a glass slide and fixed with acetone at $4^{\circ} \mathrm{C}$, air dried, and stored at $-85^{\circ} \mathrm{C}$ until tested. The indirect immunofluorescence technique was used for the eventual identification in accordance with the study guidelines. ${ }^{15}$ Viruses sought in each smear were limited to the six for which antisera were available. These comprised bovine antisera specific for respiratory syncytial virus (RSV), parainfluenza (PIV) type 3, and influenza virus type $A$ (Flu A), and chick antisera was used for PIV type 1, influenza type B (Flu B), and adenovirus. These antisera, as well as the anti-bovine/anti-chick immunoglobulins, were obtained commercially from Wellcome Diagnostics (Dartford, UK). Each spot of the smear was covered with specific antiserum and, after further processing, treated with fluorescein isothiocyanate-conjugated antibody (1:40 dilution) to chick/ bovine immunoglobulin. The slide was then counterstained and examined by two experienced virologists using a Lietz immunofluorescence microscope with a mercury vapour lamp. Slides with a paucity of cell deposits ( $<200$ cells) were excluded from further analysis. Positive and negative antigens and antisera (Wellcome Diagnostics) were included as controls in each test batch for verification of the fluorescent reaction. Each specimen was screened for each of the six viruses in duplicate. All initially positive samples were retested following the same procedure while equivocal samples were regarded as negative.

\section{Serodiagnostic technique}

The venous blood specimens were clotted overnight (at $\left.4^{\circ} \mathrm{C}\right)$. Serum separation was by cent- 
rifugation at $1500 \mathrm{rpm}$ for five minutes after which the samples were stored frozen at $-20^{\circ} \mathrm{C}$ until tested. Samples, along with their positive and negative controls, were diluted in 1:4 veronal buffer and inactivated by heating at $56^{\circ} \mathrm{C}$ for 30 minutes. Each sample was tested in duplicate using the microtitre complement fixation technique as modified by Sever. ${ }^{16}$ Seven viruses were sought including the six under immunofluorescence analyses and, in addition, PIV type 2. Quality controlled antigens (for the seven viruses) and their reference positive and negative serum samples were obtained from Behring (Marburg, Germany). Other reagents included pretitrated guinea pig complement (two haemolytic units) and 4\% sensitised sheep red blood cells in veronal buffer. Serological testings were done in Ushaped microtitre plates (Nunc, Denmark). Further details of the laboratory procedures used are provided in an earlier seroepidemiological report from our laboratory. ${ }^{17}$ A fourfold antibody rise in paired serum samples for each of the putative viruses was regarded as a positive serodiagnosis.

\section{BACTERIOLOGICAL STUDIES}

Using the rayon-tipped end of a swab stick in a sterile disposable system (Culturette, Marion Scientific, Kansas City, USA) the throat swab specimen was inoculated into the capsule of the unit containing $0.5 \mathrm{ml}$ of modified Stuart medium. The specimen was delivered to the laboratory within 20 minutes of collection. Cultures were made on blood agar and supplemented chocolate agar (Difco, Detroit, USA). About $3 \mathrm{ml}$ of the venous blood obtained was inoculated into a blood culture bottle containing $10 \mathrm{ml}$ of tryptose soy broth (TSB, Difco, Detroit, USA) with $0.25 \%$ polyanetholesulphonic acid sodium salt and $1 \%$ hydrolysed gelatin (Sigma Chemicals, St Louis, USA). Subsequent culture (for aerobic agents) was made using sheep blood agar to avert possible antimicrobial inhibition from human blood. Four subcultures were made blindly on supplemented chocolate agar before and after incubation. Standard laboratory procedures, in accordance with the parent study guidelines on bacteriological diagnosis, ${ }^{18}$ were used for the isolations of the target bacterial agents.

\section{HAEMATOLOGICAL INVESTIGATION}

Haematological indices were determined from the blood films prepared from $2-3 \mathrm{ml}$ of the venous blood sample obtained. Standard haematological laboratory techniques were used.

\section{TREATMENT}

Bronchodilators given comprised subcutaneous adrenaline (1:1000 dilution), and/or intravenous aminophylline, these being the two most readily available in our setting. Humidified oxygen, when available, was offered (through a face mask or an intranasal tube) to hospitalised subjects only. Those with a fairly prolonged attack, in whom a clinical suspicion of metabolic acidosis was considered, had empirical $8.4 \%$ sodium bicarbonate $(1-2 \mathrm{ml} / \mathrm{kg}$, diluted 1:3). In patients admitted to the children's emergency ward on account of persistent symptoms or severe acute asthma, additional therapeutic measures included a continuous infusion of aminophylline $(0.9 \mathrm{mg} / \mathrm{kg} / \mathrm{h})$ as well as systemic steroid (hydrocortisone and/ or prednisolone). Antimicrobial agents comprising one or more of benzyl penicillin, ampicillin/amoxycillin, cloxacillin, erythromycin, and co-trimoxazole were initiated only when subjects presented with two or more of the following symptoms: (1) cough that was productive of purulent sputum (with or without chest pain); (2) significant pyrexia (axillary temperature $>38.0^{\circ} \mathrm{C}$ ); and (3) clinical and/ or radiological signs of associated pneumonia. Antimalarial treatment (chloroquine) was initiated in subjects presenting with an axillary temperature of $>38.5^{\circ} \mathrm{C}$ and/or a positive blood film.

\section{DATA ANALYSIS}

The clinical and laboratory data of each subject were recorded on a precoded questionnaire/ proforma. After appropriate tabulations of the relevant pooled data, significant associations were explored using the $\chi^{2}$ test with Yates's correction or the Fisher's exact test as appropriate; $\mathrm{p}<0.05$ was considered significant.

\section{Results}

During the study period 86 episodes of acute asthma were evaluated in 86 known asthmatic patients for clinical and laboratory clues of acute respiratory infection(s). Forty six episodes $(53.5 \%)$ were seen during the dry season (October-March), while the remaining 40 episodes $(46.5 \%)$ occurred during the rainy months of April-September. The mean age of subjects was 27 months (range 6 months-12 years); $48(55 \cdot 8 \%)$ were five years or under. The male:female ratio was $1 \cdot 6: 1$. Thirty eight of the subjects (44\%) were considered to be sleeping in overcrowded rooms using four or more persons/room as the yardstick.

CLINICAL PARAMETERS AND MEDICATIONS Using the local reference chart, ${ }^{14} 29$ subjects (34\%) plotted above the 50th centile for both weight and height while 50 cases $(58 \cdot 1 \%)$ weighed $>80 \%$ of the expected for age. Thirty four cases $(39.5 \%)$ were underweight while there was one case each of marasmus and obesity. Besides the clinical features of acute asthma (detailed earlier) in the 86 subjects, symptoms and signs of a concomitant upper respiratory infection were frequently identified at recruitment. Rhinorrhoea was identified alone or associated with throat hyperaemia in $64(74.4 \%)$ cases, $51(59 \cdot 3 \%)$ of whom had an axillary temperature of $\geqslant 37.6^{\circ} \mathrm{C}$ on admission. In 11 cases the temperature was $\geqslant 38 \cdot 5^{\circ} \mathrm{C}$. Sore throat was, however, a com- 
Table 1 Bacterial cultures of throat swabs and blood

\begin{tabular}{lrr}
\hline Specimen & No. of patients & \% of total \\
\hline Throat swab & & \\
Normal flora & 76 & $88 \cdot 3$ \\
Haemophilus influenzae & 3 & $3 \cdot 5$ \\
Coliforms & 1 & $1 \cdot 2$ \\
No growth & 1 & $1 \cdot 2$ \\
Contaminated plates & 5 & $5 \cdot 8$ \\
Total & 86 & $100 \cdot 0$ \\
& & \\
Blood culture & 80 & $93 \cdot 0$ \\
Sterile & 2 & $2 \cdot 3$ \\
Contaminated plates & 1 & $1 \cdot 2$ \\
Staphylococcus aureus & 1 & $1 \cdot 2$ \\
Aerobic spore bearer & 2 & $2 \cdot 3$ \\
No report & 86 & $100 \cdot 0$ \\
Total &
\end{tabular}

plaint in only five subjects, all of whom were aged over five years.

Of the nine $(10 \cdot 5 \%)$ subjects who had had antibacterial agents before consultation, seven had co-trimoxazole while one each had ampicillin and erythromycin. Other home administered medications included oral bronchodilators (frequently salbutamol) in 61 $(70.9 \%)$ cases and cough mixture in 53 $(61 \cdot 6 \%)$. Antibiotic therapy was instituted in $20(23 \cdot 2 \%)$ cases after consultation, including the nine requiring overnight admission or longer. All nine cases had $4.3 \%$ dextrose in $20 \%$ normal saline and intravenous sodium bicarbonate $(8 \cdot 4 \%$ solution diluted).

\section{RADIOLOGICAL FINDINGS}

Only $51(59 \cdot 3 \%)$ of the 86 cases had a chest radiograph because requests for radiographs were not always honoured promptly (except in dire emergencies); many cases were given fresh appointments which were considered belated for therapeutic relevance. Of the 51 chest radiographs performed, no obvious abnormality was identified in 16 cases $(31 \cdot 4 \%)$. Twenty five $(49 \%)$ (including six of those with severe acute asthma) had radiographic features of hyperinflation. These comprised one or more of flattening of the diaphragmatic domes, horizontal ribs, and relatively hyperluscent fields. Inflammatory changes were identified in 10 cases $(19.6 \%)$; in eight, the changes were lim-

Table 2 Viral identifications in 39 virus positive cases of acute asthma

\begin{tabular}{|c|c|c|c|c|}
\hline \multirow[t]{2}{*}{ Virus } & \multicolumn{3}{|c|}{ Virological technique* } & \multirow{2}{*}{$\begin{array}{l}\text { IF or } C F T \\
\text { (total for both) }\end{array}$} \\
\hline & $\begin{array}{l}\text { IF positive } \\
\text { specimens }\end{array}$ & $\begin{array}{l}\text { CFT positive } \\
\text { specimens }\end{array}$ & $\begin{array}{l}\text { IF and CFT positive } \\
\text { for same virus }\end{array}$ & \\
\hline RSV & 18 & 12 & 10 & $\begin{array}{c}20 \\
(30)\end{array}$ \\
\hline Parainfluenza 3 & 14 & 4 & 3 & $\begin{array}{l}15 \\
(18)\end{array}$ \\
\hline Parainfluenza 2 & - & 2 & 0 & $\begin{array}{c}2 \\
(2)\end{array}$ \\
\hline Parainfluenza 1 & 4 & 0 & 0 & $\begin{array}{c}4 \\
(4)\end{array}$ \\
\hline Influenza A & 6 & 9 & 3 & $\begin{array}{l}12 \\
(15)\end{array}$ \\
\hline Influenza B & 0 & 0 & 0 & $\begin{array}{c}0 \\
(0)\end{array}$ \\
\hline Adenovirus & 1 & 2 & 1 & $\begin{array}{l}2 \\
(3)\end{array}$ \\
\hline Total & 43 & 29 & 17 & $55+(72)$ \\
\hline
\end{tabular}

RSV = respiratory syncytial virus; $I F=$ immunofluorescence; $C F T=$ complement fixation test. *A total of 107 virological analyses (comprising $60 \mathrm{IF}$ studies and 47 CFTs) were carried out in 74 subjects.

tAccounted for by the presence of dual viral positivity in $16(41.0 \%)$ of the 39 cases. ited to perihilar interstitial streakiness while lobar or segmental lesions were reported in only two cases.

\section{MICROBIOLOGICAL FINDINGS \\ Bacteriological}

The results of the throat swab and blood cultures are shown in table 1 . Bacterial agents considered as normal flora (namely one or more of Streptococcus viridans, Staphylococcus epidermidis, and Neisseria species) were isolated from $76(88.3 \%)$ throat swab cultures. Nontypable $H$ influenzae was identified in three cases $(3 \cdot 5 \%)$, only one of whom had concomitant clinical features of a possible bacterial pharyngitis (cervical lymphadenopathy and hyperaemic pharynx) together with severe wheezy dyspnoea and a high fever. Although the child was hospitalised for three days, the pattern of symptom resolution and the initial haemogram were inconsistent with a bacterial aetiology and hence erythromycin was discontinued on day 2. One other case whose blood culture eventually grew a coliform had been discharged home after four hours of a sustained improvement following intravenous aminophylline.

As shown in table 1, the blood culture proved sterile in $80(93 \%)$ of the 86 cases while contaminants were isolated in two other cases $(2 \cdot 3 \%)$. One case each grew Staphylococcus aureus and aerobic spore bearers; neither of the two cases (one of whom had perihilar interstitial changes on the chest radiograph) was clinically septicaemic.

\section{Virological}

Of the 86 nasopharyngeal aspirate specimens, results of immunofluorescence studies were available in 60 cases; the remaining 26 were reported unsuitable for further processing, either because of late delivery or paucity of cell pellets as mentioned earlier. Only 47 paired serum samples were examined because the convalescence samples were not available in the remaining 39 cases, either because they failed to turn up at the clinic or because they came at a time that was inappropriate for specimen collection. In all, a total of 107 virological specimens from 74 subjects was tested. These comprised 60 nasopharyngeal aspirates for immunofluorescence studies and 47 paired serum samples for significant seroconversion. The remaining 12 cases in whom neither of the two investigations was performed were excluded from further statistical testing with respect to the virological findings. As shown in table 2, 55 viruses were identified by either immunofluorescence or serological tests in $39(53 \%)$ of the 74 cases tested; $16(41.0 \%)$ had dual viral identifications. RSV accounted for $20(36.4 \%)$ of the 55 positive identifications, PIV type 3 for $15(27 \cdot 3 \%)$, while $12(21 \cdot 8 \%)$ cases had influenza type A infection. Only two cases (both of whom were aged over five years) proved positive for adenovirus. Furthermore, RSV was most commonly identified in infant wheezers and those below five years, while 
Table 3 Age distribution of 39 virus positive cases of acute asthma

\begin{tabular}{lllllll}
\hline Virus & \multicolumn{3}{l}{ Age groups in years } & Total & p value $\dagger$ \\
\cline { 2 - 5 } & $\begin{array}{l}<1 \\
(n=6)\end{array}$ & $\begin{array}{l}1-5 \\
(n=20)\end{array}$ & $\begin{array}{l}\leqslant 5 \\
(n=26)\end{array}$ & $\begin{array}{l}>5 \\
(n=13)\end{array}$ & $(n=39)$ & \\
\hline RSV & 5 & 11 & 16 & 4 & 20 & $>0 \cdot 1$ \\
Parainfluenza 3 & 1 & 6 & 7 & 8 & 15 & $>0 \cdot 1$ \\
Parainfluenza 2 & 0 & 1 & 1 & 1 & 2 & $>0 \cdot 5$ \\
Parainfluenza 1 & 2 & 1 & 3 & 1 & 4 & $>0 \cdot 5$ \\
Influenza A & 1 & 8 & 9 & 3 & 12 & $>0 \cdot 1$ \\
Influenza B & 0 & 0 & 0 & 0 & 0 & - \\
Adenovirus & 0 & 0 & 0 & 2 & 2 & $>0 \cdot 1$ \\
Total* (No. with >1 virus) & $9(3)$ & $27(7)$ & $36(10)$ & $19(6)$ & $55(16)$ & \\
\hline
\end{tabular}

* Of the 74 subjects tested the distribution of the 39 positive cases was significantly different in the three age groups $(p<0.05)$ (see table 4$)$.

† Positive identifications in preschool subjects ( $<5$ years) $v$ cases $>5$ years (Yates' corrected $\chi^{2}$ values or Fisher's exact test in appropriate cases).

$\mp$ Obtained from statistical testing of the distribution of the top two viral pathogens (RSV and parainfluenza 3$)$ in preschool subjects $(<5$ years) $v$ cases $>5$ years.

PIV type 3 infections were more common in subjects older than five years and (to lesser extent) those aged between one and five years. There was a significant difference in the distribution of these two agents (RSV and PIV type 3) between preschool subjects ( $<5$ years) and those aged more than 5 years $(p<0.05)$ (table 3). Flu A identifications were most frequently made in subjects aged $1-5$ years, but the distribution was not significantly different amongst the age groups tested.

\section{HAEMATOLOGICAL FINDINGS}

Forty eight cases were screened; the haematocrit values in these ranged between $29 \%$ and $44 \%$ (mean $37 \%$ ) while the total WBC range was $2.9-14.1 \times 10^{9} / 1$ (mean $7 \cdot 3 \times 10^{9} / 1$ ). The mean eosinophil count was $0.76 \times 10^{9} / 1$ (range $\left.0-3.3 \times 10^{9} / 1\right)$. Eosinophilia $\left(>0.4 \times 10^{9} /\right.$ 1) was reported in $26(54 \cdot 2 \%)$ cases.

RELATIONSHIP BETWEEN VIRUSES AND SELECTED SOCIODEMOGRAPHIC, CLINICAL AND NON-SPECIFIC INVESTIGATIVE FINDINGS

In order to identify "soft" clues of a possible viral aetiology in an asthmatic child presenting with concomitant symptoms of acute res-

Table 4 Relationship between viral identifications and selected demographic, clinical, and radiographic parameters

\begin{tabular}{|c|c|c|c|}
\hline Parameter* & $\begin{array}{l}\text { No. of cases with } \\
\text { positive identification(s) }\end{array}$ & $\begin{array}{l}\text { No. of cases } \\
\text { studied }\end{array}$ & $\begin{array}{l}p \text { valuet } \\
\left(\chi^{2} ; d f\right)\end{array}$ \\
\hline $\begin{array}{l}\text { Age group (years) } \\
<1 \\
1-5 \\
>5\end{array}$ & $\begin{array}{r}6 \\
20 \\
13\end{array}$ & $\begin{array}{r}6 \\
37 \\
31\end{array}$ & $\begin{array}{l}<0 \cdot 05 \\
(6 \cdot 854 ; 2)\end{array}$ \\
\hline $\begin{array}{l}\text { Nutritional status } \ddagger \\
\text { Satisfactory } \\
\text { Underweight }\end{array}$ & $\begin{array}{l}25 \\
14\end{array}$ & $\begin{array}{l}44 \\
30\end{array}$ & $\begin{array}{l}\text { NS } \\
(0 \cdot 386 ; 1)\end{array}$ \\
\hline $\begin{array}{l}\text { Rhinorrhoea } \\
\text { Present } \\
\text { Absent }\end{array}$ & $\begin{array}{l}28 \\
11\end{array}$ & $\begin{array}{l}36 \\
38\end{array}$ & $\begin{array}{l}0 \cdot 0001 \\
(15 \cdot 779 ; 1)\end{array}$ \\
\hline $\begin{array}{l}\text { Pyrexia }\left(T \geqslant 37 \cdot 6^{\circ} \mathrm{C}\right) \\
\text { Present } \\
\text { Absent }\end{array}$ & $\begin{array}{l}22 \\
17\end{array}$ & $\begin{array}{l}29 \\
45\end{array}$ & $\begin{array}{l}<0 \cdot 005 \\
(8 \cdot 790 ; 1)\end{array}$ \\
\hline $\begin{array}{l}\text { Chest radiography } \\
\text { Inflammatory changes present } \\
\text { No inflammatory changes }\end{array}$ & $\begin{array}{r}6 \\
20\end{array}$ & $\begin{array}{r}9 \\
36\end{array}$ & $\begin{array}{l}\text { NS } \\
(0.0512 ; 1)\end{array}$ \\
\hline
\end{tabular}

$\mathrm{df}=$ degrees of freedom; NS $=$ not significant.

* Five other parameters (sex, season of presentation, paternal income status, household crowding, and initial white cell counts) were tested; none proved significant.

+ Virus positive $v$ virus negative (Yates' corrected $\chi^{2}$ values or Fisher's exact test).

$¥$ Categorisation based on the local reference chart ${ }^{13}$ and the Wellcome classification. ${ }^{14}$ piratory infection, some selected sociodemographic variables, clinical, and nonspecific investigative findings were analysed with respect to the viruses identified. The low bacterial isolation rates (from the throat swabs and blood cultures) precluded a similar analysis of the same parameters with respect to bacterial isolates. As shown in table 4, significantly higher positive viral identifications were obtained in infants $(100 \%)$ and those aged 1-5 years $(54 \%)(p<0.05)$. Those with either rhinorrhoea or pyrexia at presentation also had significantly higher positive viral identifications $(p=0.0001$ and $<0.005$, respectively). Neither the season of presentation, overcrowding, paternal income status, sex, nutritional status, the presence of inflammatory changes on the chest radiograph, nor an initial leucocytosis was significantly associated with a positive viral identification.

\section{Discussion}

The clinical scenario of a toddler, with a family history of atopy, presenting with recurrent episodic cough and wheezy breathlessness usually associated with a cold is frequently re-enacted in our paediatric practice. Although the symptoms usually resolve with appropriate supportive care and bronchodilator(s), many tropical practitioners would elect to initiate antibiotic therapy in such cases. The reasons for this include the inadequate laboratory facilities and reportedly higher prevalence of bacterial pneumonia in the developing world. ${ }^{419}$ Clearly, the risk of emergence of drug-resistant bacterial pathogens is a potentially serious consequence of this practice, and this concern has motivated the current study.

The viral identification rate of $53 \%$ in the current study is slightly higher than the $10-50 \%$ range reported in most temperate countries. ${ }^{20}$ This, coupled with the relatively high dual identification rate, raises the possibility of some false positive identifications. Considering the usual laboratory constraints of viral identification, Pattemore et $a l^{20}$ observed that false negative rather than false positive results are more likely. Our less than optimal virological techniques (immunofluorescence and serology only), and the limited spectrum of viruses explored, are therefore more likely to underestimate the role of viral inciters in view of some inevitable false negative identifications. This latter possibility is likely to counterbalance a conceivably exaggerated role of viral inciters (in acute asthma) occasioned by possible false positive results. The identification rate in the present study is, however, higher than expected. Hence, even allowing for significant false positives, our virological findings are in keeping with those reported in western communities. The absence of a control group makes it difficult to ascertain the pathogenic significance of the agents in view of an earlier report with regard to influenza $\mathrm{A}$ virus identification in asymptomatic Nigerian children. ${ }^{21}$ However, previous controlled studies have observed a low identification rate $(\leqslant 3 \%)$ in asymptomatic asthmatic and non-asthmatic subjects. ${ }^{7223}$ 
That RSV was the commonest agent in the present study, in which rhinovirus identification was not explored, is consistent with previous observations $^{524}$ and probably reflects the preponderance of subjects in the vulnerable age groups - that is, infants and preschool subjects. ${ }^{2425}$ The significantly higher viral identifications in younger subjects also underscores the reported age-dependent relationship between viral acute respiratory infection and acute asthma. ${ }^{2025}$ Similarly, the relatively higher prevalence of PIV infection and Flu $A$ in older subjects is consistent with the findings of previous reports. ${ }^{568}$ The high frequency of PIV type 3 in the present study, rather than the type 2 infection observed earlier by McIntosh et $a l,{ }^{5}$ corroborates recent tropical observations. ${ }^{2627}$ The inevitable laboratory and logistic constraints of the present study are acknowledged, but the findings are of sufficient interest to justify future studies, preferably using more sensitive techniques such as the polymerase chain reaction, and exploring a wider spectrum of pathogens. Such studies are inevitable for local optimisation of future preventative vaccination options, the future reality of which is evident from the reported efficacy of influenza vaccination in frequent asthma exacerbations. ${ }^{28}$

In contrast to the high rate of viral identification, microbiological evidence of bacterial acute respiratory infection was absent in an overwhelming proportion of our subjects. Throat swab culture (for bacterial agents) was selected because most of the relevant literature on infective inciters of acute asthma has identified an association with upper, rather than lower, respiratory infections. ${ }^{8202529-31}$ However, in view of the high relative risk of bacterial pneumonia in the tropics ${ }^{419}$ (frequently preceded by a viral upper respiratory infection), investigative clues of a concomitant acute lower respiratory infection of bacterial aetiology were also sought. The paucity of clinical features of bacterial pharyngitis, even among the small proportion of cases with a positive throat swab, suggests that the putative bacterial agents may be commensals. In exploring a bacterial aetiology of acute lower respiratory infection, the choice of blood culture, rather than sputum culture or more sensitive techniques such as cultures of lung aspirate, transtracheal aspirate or bronchoalveolar lavage material, was dictated by ethical and logistic considerations. Aspirate studies in acute asthma were disallowed on ethical grounds, facilities for obtaining bronchoalveolar lavage fluid was nonexistent, and phlegm was difficult to obtain from young asthmatics, especially during acute exacerbations. Nevertheless, the low positive blood culture isolates in our subjects is comparable with those of earlier reports based on transtracheal aspirates ${ }^{32}$ and sputum cultures. ${ }^{29}$ Furthermore, the lack of consolidative radiographic changes of bacterial pneumonia ${ }^{33}$ is consistent with the absence of microbiological evidence of a bacterial infection in our subjects. Thus, in accordance with the recommendations in recent management guidelines, ${ }^{3435}$ our findings suggest that, even in a tropical setting, acute respiratory infections of bacterial aetiology are sufficiently uncommon in acute asthma to warrant a routine antibiotic cover.

While the precise mechanisms of acute respiratory infection-triggered asthma exacerbations remain largely unknown, a postnasal drip theory has been suggested in bacterial sinusitis. ${ }^{36}$ With regard to acute asthma associated with viral acute respiratory infection, earlier suggestions included virusinduced vagal reflex mechanisms, ${ }^{30}$ enhanced mucosal permeability to potential allergens following epithelial damage, ${ }^{37}$ and a virus-specific IgE-mediated hypersensitivity reaction. ${ }^{3839}$ The current consensus, however, is that respiratory viruses incite airway hyperresponsiveness by one or more interrelated mechanisms which predispose to the development of airway inflammation. ${ }^{25}$ These include "priming" of the inflammatory cells associated with the late phase allergic response, ${ }^{31}$ enhanced leucocyte inflammatory function by virus-induced production of regulatory cytokines, ${ }^{40}$ and a virus modulated expression of a receptor molecule, the intercellular adhesion molecule 1 (ICAM-1). Increased expression of airway and vascular endothelial ICAM-1 (sequel to viral epithelial damage) would undoubtedly upregulate the cell-mediated immune response by enhancing $\mathrm{T}$ lymphocyte recruitment, activation, and interstitial migration. Although best documented for rhinovirus infections, ${ }^{41}{ }^{42}$ the ICAM-1 model has also been suggested for RSV and PIV-associated asthma exacerbations ${ }^{43}$ which were frequently identified in the present study. These current insights into the central role of virus-enhanced airway inflammation in acute asthma suggest a potential therapeutic role for anti-inflammatory agents and, as suggested by our data, emphasise the futility of routine antibiotic therapy.

In a child presenting with acute asthma associated with acute respiratory infection, our results suggest that young age, rhinorrhoea, and pyrexia are pointers to a possible viral aetiology. Their incomplete immunity, ${ }^{33}$ coupled with a continuing exposure to an increasing spectrum of viral pathogens, may account for the vulnerability of younger subjects. The higher viral identifications in cases with pyrexia and rhinorrhoea would indicate an infective aetiology rather than possible flares of a concomitant allergic rhinitis. The low prevalence of subjects with severe malnutrition states such as kwashiorkor may be explained by the reported suboptimal immune response in kwashiorkor ${ }^{44}$ with a consequent effect on the immunological cascades associated with acute asthma. That neither inflammatory changes on the chest radiograph nor an initial leucocytosis was individually associated with a positive viral identification emphasises the inherently poor predictive value of isolated investigative parameters.

These data suggest that viruses, rather than bacterial agents, are the important agents in acute asthma associated with acute respiratory infection in the tropics. However, the inevitable logistic limitations and the suboptimal sens- 
itivity of our laboratory techniques would preclude firm conclusions and further studies using more sensitive techniques are needed.

The authors acknowledge the contributions of Residents in the Department of Paediatrics for their logistic support at the stag of data collection, Drs Rotowa and Adeyemi-Doro for their help in the bacteriological studies, and Mr O A Olabode, Pro fessor A H Fagbami, and Professor O Tomori in the virological analyses. They are particularly indebted to Drs J B Clough, SL Johnston, and Professor JO Warner for their invaluable suggestions and encouragement during the preparation of the suggestions and encouragement during the preparation of

manuscript. $M r$ 'Kunle Ojo provided secretarial assistance.
Financial/technical support for this study was partly provided

Financial/technical support for this study was partly provided
by the United States National Academy of Sciences/Research Council through a grant (to WIA) from the Board of Studies for International Development (BOSTID Grant No ARI-NGfor Inte

1 Aderele WI. Bronchial asthma in Nigerian children. Arch Dis Child 1979;54:448-53.

2 Anim T, Edoo BB. Bronchial asthma at the Korle Bu teaching hospital: a preliminary report. Ghana Med $f$ 1972;1:59-61.

3 Burr ML, Butland BK, King S, Vaughan-Williams E. Changes in asthma prevalence: two surveys 15 years apart. Arch Dis Child 1989;64:1452-6.

4 Pio A, Leowski J, ten-Dam HG. The magnitude of the problem of acute respiratory infections in developing countries. In: Douglas RM, Kerby-Easton E, eds Acute respiratory infections in childhood. Proceedings of an international workshop. University of Adelaide, Australia, 1985:3-16.

5 McIntosh K, Ellis EF, Hoffman LS, Lybass TG, Eller JJ, Fulginiti VA. The association of viral and bacterial J, Fulginiti VA. The association of viral and bacterial respiratory infections with exacerbations of wheezing

6 Minor TE, Dick EC, Baker JW, Oullette JJ, Cohen M, Reed CE. Rhinovirus and influenza type $A$ infections as precipitants of asthma. Am Rev Respir Dis 1976;113: $149-53$.

7 Mitchell I, Iglis JM, Simpson KP. Viral infection as a precipitant of wheeze in children: combined home and hospital study. Arch Dis Child 1978;53:106-11.

8 Roldaan AC, Mansural N. Viral respiratory infections in asthmatic children staying in a mountain resort. Eur $\mathfrak{f}$ asthmatic children staying

9 Aderele WI. Aetiologic, precipitating and environmental factors in childhood asthma. Nig $\mathcal{F}$ Paediatr 1982;9:26-31.

10 Oyejide CO, Osinusi K. Acute respiratory infections in children in Idikan Community, Ibadan, Nigeria: severity, risk factors and frequency of occurrence. Rev Infect Dis 1990;12(Suppl 8):S1042-6.

11 Crofton J, Douglas A. Respiratory diseases. 3rd edn. Oxford Blackwell Scientific Publications, 1981:478-515.

12 Bierman CW, Pearlman DS. Asthma. In: Kendig EL Jr, Chernick V, eds. Disorders of the respiratory tract in children. Philadelphia: WB Saunders, 1983:496-543.

13 Janes MD. Physical growth of Nigerian Yoruba children. Trop Geogr Med 1974;26:389-98.

14 Wellcome Classification. Classification of infantile mal nutrition. Lancet 1970;ii:302-3.

15 Manual of laboratory procedures for diagnosis of respiratory virus infections. Washington DC: Board of Science and Technology for International Development (BOSTID) Research Program, 1986.

16 Sever JL. Application of microtechnique to viral serological investigations. F Immunol 1962;88:320-4.

17 Olaleye OD, Olawuyi AO, Baba SS. Sero-epidemiological studies of respiratory syncytial and adenoviruses in Ibadan, Nigeria, 1985-1988. Trans $R$ Soc Trop Med Hyg 1992;86: Nigeria,

18 Manual of laboratory procedures for respiratory bacterial pathogens. Washington DC: BOSTID Research Grants Program on Etiology and Epidemiology of Acute Respiratory Infections in Children, 1986

19 Shann FA, Gratten M, Germer S, Linnemann V, Hazlett $D$, Payne R. Aetiology of pneumonia in children in Gorok Hospital, Papua New Guinea. Lancet 1984;ii:537-41.

20 Pattemore PK, Johnston SL, Bardin PG. Viruses as precipitants of asthma symptoms I. Epidemiology. Clin Exp Allengy 1992;22:325-36.
21 Oshin OO. Enzyme immunoassay of antibodies to influenza A virus in Nigerian children. Trop Geogr Med 1979;31: 509-17.

22 Horn MEC, Brain EA, Gregg I, Inglis JM, Yealland SJ, Taylor P. Respiratory viral infection and wheezy bronchitis in childhood. Thorax 1979;34:23-8.

23 Jennings LC, Barns G, Dawson KP. The association of viruses with acute asthma. NZ Med $\mathcal{F}$ 1987;100:488-90.

24 Carlsen KH, Orstavik I, Leegaard J. Respiratory virus infections and aeroallergens in acute bronchial asthma. Arch Dis Child 1984;59:310-5.

25 Cypcar D, Stark J, Lemanske RF Jr. The impact of respiratory infections on asthma. Pediatr Clin North Am 1992 piratory infectic

26 Puthavathana $P$, Wasi C, Kositanont U, Suwanjutha S Chantarojanasiri T, Kantakamalakul W, et al. A hospitalbased study of acute viral infections of the respiratory tract in Thai children, with emphasis on laboratory diagnosis. Rev Infect Dis 1990; 12(Suppl 8):S988-94.

27 Johnson 'WBR, Osinusi K, Aderele WI, Tomori O. Vira pathogens of acute lower respiratory infections in preschool Nigerian children and clinical implications of multiple microbial identifications. W Afr $\mathcal{F}$ Med 1993;12 11-20.

28 Bell ID, Chai H, Berlow B, Daniels G. Immunisation with killed influenza virus in children with chronic asthma. Chest 1978;73:187-92.

29 Horn MEC, Reed SE, Taylor P. Role of viruses and bacterial in acute wheezy bronchitis in childhood: a sputum study. Arch Dis Child 1979;54:587-92.

30 Empey DW, Laitinen LA, Jacobs L, Gold WM, Nade JA. Mechanisms of bronchial hyperreactivity in norma subjects after upper respiratory tract infection. Am Rev Respir Dis 1976;113:131-9.

31 Lemanske RF, Dick EC, Swenson CA, Vrtis RF, Busse WW. Rhinovirus upper respiratory infection increases airway hyperreactivity and late asthmatic reaction. $f$ Clin Invest 1989;83:1-10.

32 Berman SZ, Mathison DA Stevenson DD, Tan EM Vaughan JH. Transtracheal aspiration studies in asthmatic patients in relapse with "infective" asthma and in subjects without respiratory disease. F Allergy Clin Immunol 1975 56:206-14.

33 Long SS. Treatment of acute pneumonia in children. Pediatr Clin North Am 1983;30:297-322.

34 Warner JO, Götz M, Landau LI, Levison H, Milner AD, Pendersen S, et al. Management of asthma: a consensus statement. Arch Dis Child 1989;64:1065-79.

35 International consensus report on diagnosis and management of asthma. Bethesda, Maryland: National Heart, Lung and asthma. Bethesda, Maryland: National Heart, Lung and Blood Institute and Nation

36 Slavin RG, Cannon RE, Friedman WH, Palitang E, Sunderam M. Sinusitis and bronchial asthma. f Allergy Clin Immunol 1980;66:250-7.

37 Gershwin LJ, Osebold JW, Zee YC. Immunoglobulin Econtaining cells in mouse following allergen inhalation and ozone exposure. Int Arch Allergy Appl Immunol 1981 98:266-71.

38 Welliver RC, Wong DT, Sun M, Middleton E Jr, Vaughan RS, Ogra PL. The development of respiratory syncytial virus-specific IgE and the release of histamine in nasopharyngeal secretion after infection. $N$ Engl $₹$ Med 1981 . pharyngeal

39 Welliver RC, Wong DT, Middleton E, Sun M, McCarthy N, Ogra PL. Role of parainfluenza virus-specific IgE in pathogenesis of croup and wheezing subsequent to infection. F Pediatr 1982;101:889-96.

40 Becker S, Quay J, Sonkup J. Cytokine (TNF, IL-6, and IL-8) production by respiratory syncytial virus-infected human alveolar macrophages. F Immunol 1991;147:4307 16.

41 Montefort S, Holgate ST. Adhesion molecules and their role in inflammation. Respir Med 1991;85:91-9.

42 Staunton DE, Merluzzi VJ, Rothlein R, Barton $R$, Martin $\mathrm{SD}$, Springer TA. A cell adhesion molecule, ICAM-1, is the major surface receptor for rhinoviruses. Cell 1989;56: 849-53.

43 Tosi MF, Stark JM, Hamedani A. Neutrophil adhesion to human airway treated with IL-1 or TNF. Pediatr Pulmonol 1991;Suppl. 6:301-10

44 Kielman AA, Uberri IS, Chandra RK, Mehra VL. The effect of nutritional status on immune capacity and immune responses in pre-school children in a rural community in India. Bull WHO 1976;54:477-83. 